BETSJOEANALAND-PROTEKTORAAT: EKONOMIESE

\title{
STRUKTUUR EN VOORWAARDES VIR ONTWIKKELING*
}

\section{Inleiding}

Betsjoeanaland-protektoraat is die grootste van die drie Britse protektorate in suidelike Afrika. Dit word in die suide en ooste begrens deur die Republiek van SuidAfrika, in die noorde hoofsaaklik deur Suid- en NoordRhodesië en in die weste deur Suidwes-Afrika. As 'n geheel is die gebied nog nie opgemeet nie, maar die oppervlakte word op 225,000 vk. myl geraam, wat ongeveer dieselfde oppervlakte beslaan as die Transvaal, OranjeVrystaat en Basoetoland.

Die vernaamste kenmerk van die gebied is die gebrekkige watervoorrade wat sy ontwikkeling strem. Die afloopwater van die oostelike gedeelte van die gebied vloei hoofsaaklik in die Notwani- en Shashi-riviere na die Limpopo. Eersgenoemde twee riviere vloei gedurende die reënseisoen slegs kort periodes en is die res van die jaar feitlik net droë sandbeddings, alhoewel poele water tot diep in die herfs aangetref word. Selfs die Limpopo wat die oostelike grens vorm, is nie standhoudend nie. Die water van die sentrale en suidelike Kalahari het vroeër in die Molopo-, Nosop- en Auobriviere na die Oranjerivier gevloei. Vandag vloei hierdie sytakke egter nie meer nie.

Die enigste redelik permanente bogrondse watervoorrade word gevind in die Okovango-, Chobe- en Zambesiriviere in die noorde. Met uitsondering van die ondergrondse vloei in die rigting van die Makgadikgadi-

\footnotetext{
* Die referent is Direkteur van die Ekonomiese Instituut aan die P.U. vir C.H.O.
} 
laagte waar dit in fonteine ontspring, verdamp die hele vloei van die Okovangorivier in die moerasse of in die Botletlerivier. Die met papirus- en rietbegroeide Okovangorivier word tans deur die Administrasie oopgekap in 'n poging om water in die Ngamimeer te laat vloei wat besig is om op te droog. Die Natarivier in die ooste vloei ook in die Makgadikgadi.

Behalwe in die noordweste is die skaarste aan bogrondse water waarskynlik die grootste enkele natuurlike probleem waarmee die inwoners van die gebied te kampe het. Plek-plek word deur middel van die dieper maak van panne en die bou van damme en sink van boorgate gepoog om die watervoorraad te vergroot. Die Notwanidam wat onlangs in die Notwanirivier voltooi is, het 'n kapasiteit van 430 miljoen gelling wat water aan die spoorweë en Gaberones voorsien.

Reënvalstatistiek is baie onvolledig en dek in die meeste gevalle slegs relatiewe kort periodes. Die gemiddelde reënval vir die hele protektoraat is ongeveer $18 \mathrm{dm}$. maar varieer van $27 \mathrm{dm}$. in die noorde tot $9 \mathrm{dm}$. of minder in die Kalahari.

Die winterklimaat (Mei-Augustus) is aangenaam, maar die hitte is erg gedurende die somermaande en malaria is besonder straf in die laagliggende dele en in die nabyheid van water; ook is die tsetsevlieg in die noordweste ' $n$ bedreiging vir mens en dier.

Alhoewel die reënval relatief laag is, is dit nogtans voldoende vir die plantegroei. Die gebied is ryk aan grassoorte, struike en bome - selfs in die middel van die Kalahariwoestyn. In die suide, veral langs die rivierbeddings, staan digte doringbosse wat deur hoë bome afgewissel word. In die noorde kom uitgebreide bosse en hoë bome voor - baie met goeie timmerhout (onder andere Mukwou Pterocarpus angolensis, wat baie geskik is vir die meubelbedryf), maar groot gedeeltes is bedek met mopane (Copaifere mopane), wat in skraal grond groei. Die gras bereik dikwels kniehoogte en bied uitstekende weiveld vir beeste en ander diere wat op verskillende wyses in die behoeftes van die inwoners voorsien.

Die mineraalrykdom van die gebied is nog onontwik- 
keld. Goud word reeds vir baie jare lank in die Tatidistrik ontgin en is nie elders in genoegsame hoeveelhede vir eksploitasie ontdek nie. 'n Asbesneerslag is 'n tyd gelede reeds in die Bamangketse-reservaat ontdek en word op 'n winsgewende basis ontgin. In die voor-Blank periode is ystererts in die Tswapongheuwels deur die Bantoe ontgin en gesmelt, maar die verskaffing van metaalgoedere deur die handelaars het hierdie bedryf tot niet laat gaan. Verder is steenkool reeds op verskillende plekke deur geoloë aangewys en wag op ontginning.

Die beoefening van die akkerbou en veral veeteelt is die vernaamste vorm van produksie, terwyl die jag- en versamelbedryf beslis 'n noemenswaardige bydrae tot die bestaan van die bevolking maak.

Die beoefening van tuisnywerhede, tesame met die insameling van veldkosse het ' $n$ relatief belangrike ekonomiese betekenis. Hierteenoor lewer die verhuur van arbeidskragte aan die goudmyne en elders in die Republiek 'n baie belangrike bron van inkomste aan Betsjoeanaland.

Die ekonomiese aktiwiteite van verreweg die grootste gedeelte van die bevolking moet in vergelyking met Westerse standaarde as primitief bestempel word, en gevolglik bestaan daar geen behoefte aan die toepassing van meer produktiewe tegnieke en van 'n beter integrasie van die ekonomiese lewe van die gebied in die wêreldekonomie nie. Van al die vorms van ekonomiese bedrywighede is die bestaansekonomie nog die belangrikste. Dit is 'n stelsel waar die winsmotief feitlik geen rol speel nie en rykdom slegs in dic vorm van beeste opgebou kan word. Hier bestaan 'n gemis aan die dinamiek van die Westerse kultuur.

Volgens die jongste beskikbare sensussyfers (1956) was die samestelling van die bevolking soos volg: Bantoes ongeveer 300,000, Blankes 3,173, Kleurlinge 676 en Asiate 248. Die aard en samestelling van die bevolking in hierdie gebied is heeltemal verskillend as dié van die ander Hoëkommissarisgebiede. In teenstelling met Basoetoland, waar geen vervreemding van grond bestaan nic en waar die Blanke bevolking alleenlik uit handelaars, sen- 
delinge en staatsamptenare met enkele professionele persone in 'n stad soos Maseru bestaan, besit die Blankes in Betsjoeanaland 'n relatiewe klein gedeelte van die totale oppervlakte van die gebied. Met uitsondering van die Ghanzi-nedersetting is die Blanke blokke, nl. die Tati-, Tuli-, Lobatsi- en Gaberonesblokke almal aan die oostelike grens van die gebied geleë. Die Blanke handelaars, staatsamptenare en sendelinge binne die Bantoereservate, kan geen permanente reg op grond aldaar bekom nie elke handelaar behou sy handelsperseel solank as wat hy in besit is van ' $n$ handelslisensie aan hom uitgereik. Alle persele binne die reservate word van die stamowerheid gehuur en huurgelde is aan die stamowerheid betaalbaar. In Swaziland het Blanke nedersetting op 'n groter skaal as in Betsjoeanaland plaasgevind en gebiede wat vir die Bantoe gereserveer is, word deur Blanke gebiede afgewissel, sodat Blank en Nie-blank in gebiede langs mekaar woon. Verder bestaan daar in Basoetoland sowel as in Swaziland 'n nasionale eenheid onder die Bantoe wat gesimboliseer word deur een opperhoof wat namens die hele gebied optree. In Betsjoeanaland, daarenteen, bestaan verskillende stamme, elk met sy eie opperhoof.

Die gebied, bestaande uit kroongronde, Blanke blokke en Bantoereservate word vir administratiewe doeleindes in 12 distrikte onderverdeel, elk met sy eie Distrikskommissaris of magistraat en amptenare. Mafeking, binne die Republiek van Suid-Afrika, is die setel van die regering waar die Resident-Kommissaris, die hoofadministratiewe amptenaar onder die Hoë Kommissaris vir Basoetoland, Betsjoeanaland en Swaziland gesetel is. Tot Junie 1961 het 'n Blanke Adviserende Raad (8 lede), 'n Bantoe Adviserende Raad (37 lede) en 'n Gesamentlike Adviserende Raad ( 8 lede elk van die vorige twee rade), bestaan om slegs in adviserende hoedanigheid die belange van die gebied te bchartig. Hierdie rade is toe vervang deur 'n Wetgewende Raad (30 lede) waarvan 10 deur Blankes, 10 deur Bantoes en 1 deur die Asiate verkies word. 'n Verdere 9 word deur die Resident-Kommissaris aangestel. Binne elke Bantoereservaat word die administrasie ingevolge die stelsel van ,indirect rule" deur die 
stamkaptein behartig, d.w.s. een waaronder die Blanke owerheid die gesag van die Bantoekaptein en sy rade erken, en waarin eersgenoemde die nodige leiding gee om die politieke organisasie van die stam te laat aanpas by die Blanke plaaslike administrasie.

Verskeie politieke partye is onlangs in die lewe geroep, nl. die Betsjoeanaland-Protektoraat Federale Party, wat in 1959 gevorm is onder leiding van L. Roehtladi; die Betsjoeanalandse Volksparty geaffilieer met P. A. F. MECSA, wat in 1960 gevorm is ander leiding van $\mathrm{K}$. T. Motsete; die Betsjoeanalandse Demokratiese Party, wat in Januarie 1962 gevorm is deur Seretse Khama, die stam. sekretaris van die Bamangwato; en die Betsjoeanalandse Liberale Party, wat teen die einde van 1962 gevorm is.

Die huidige partye is hoofsaaklik vir die verskillende stamme georganiseer en almal maak daarop aanspraak om 'n nasionale gevoel onder die agt stamme te laat posvat.

Die enigste spoorweg deur die gebied is die hoofspoorweg vanaf Kaapstad na die Rhodesiës - beginnende by Ramatlabama, 886 myl van Kaapstad, en eindigende by Ramaquabane, 394 myl verder. Die enkelspoorweg loop parallel met die oostelike grens van die Protektoraat ongeveer 50 myl van die grens. Die spoorweg binne die gebied vorm deel van die ondernemings wat deur Rhodesia Railway Limited besit word en tot onlangs geheel en al deur die Suid-Afrikaanse Spoorweë en Hawens bestuur is. Die beheer oor die gedeelte van die spoorlyn van Mahalapye na Ramaquabane is toe deur die Rhodesiese spoorwegadministrasie van die S.A.S. en H. oorgeneem.

Oor die 4,500 myl paaie is in die gebied gemaak wat soos volg geklassifiseer kan word: hoofpaaie 1,195 myl, sekondêre paaie 526 myl en 2,882 myl veldpaaie (,tracks'). Die Departement van Openbare Werke is in die algemeen verantwoordelik hiervoor, maar is weens gebrek aan personeel en fondse slegs in staat om 2,300 myl daarvan werklik in stand te hou. Met uitsondering van die stukkie teerpad in Lobatsi en Francistown en 'n relatiewe klein afstand wat gegruis is, bestaan die res uit 
grond en sand. Die enigste hoofpad deur die gebied, van Mafeking na die Rhodesiës, volg dieselfde roete as die spoorweg en is saam met die ander sekondêre paaie in die onmiddellike omgewing (d.w.s. ongeveer $50 \mathrm{myl}$ oos en wes) van die hoofpad die cnigste redelik goed begaanbare paaie.

Daar bestaan geen openbare watervervoer nie, terwyl van private kanovervoer op die Okovango- en Choberiviere gebruik gemaak word.

Ten opsigte van lugvervoer kan opgemerk word dat daar klein vliegvelde op die volgende plekke aangelê is: Gaberones, Mahalapye, Francistown, Maun, Serowe, Tsabong, Ghanzi, Lobatsi, Molepolole, Palapye en Rakops.

Alhoewel die vernaamste bevolkingsentra langs die spoorweg met die Republiek en die Federasie van Rhodesië en Njassaland telegrafies verbind is en poskantoordienste besit, is groot gedeeltes van die gebied nie daarvan voorsien nie.

Benewens die radionetwerk wat deur die regeringsdepartemente vir eie gebruik in stand gehou word, bestaan daar ' $n$ aantal private radioverbindingstasies en ongeveer 2,000 gelisensieerde luisteraars.

\section{Die ekonomiese situasie}

\section{a) Landbou}

Landbou in die breë sin van die woord sluit akkerbou sowel as veeteelt in. Die moontlikhede van landbouontwikkeling en daarom van produksie word deur inherente fisiese en biologiese faktore beïnvloed, en aangesien die fisiese faktore van klimaat en grond, en stamtradisies, in Betsjoeanaland die vryheid van keuse en onderneming aan bande lê, bestaan daar nie dieselfde ontwikkelingsmoontlikhede as in die gebiede waar wel 'n vrye keuse bestaan nie.

Alhoewel die Protektoraat weens sy lae reënval en uitgestrekte weivelde verreweg meer geskik is vir veeteelt, word akkerbou nogtans in 'n sekere mate beoefen. Die gebied, alhoewel nie heeltemal selfonderhoudend nie, voorsien in 'n groot mate in sy eie graanbehoeftes. 
Die totale bewerkbare grond in die gebied word op 8 miljoen akker geskat waarvan ongeveer 400,000 akker of ongeveer 5 persent onder bewerking is. 'n Belangrike gedeelte van hierdie gebied val binne die Blanke blokke, waar sommige boere besonder goeie resultate met besproeiing het. Die Verenigde Volkere se Spesiale Fonds het brig. C. Haws, 'n Amerikaner, onlangs benoem om die moontlikhede te ondersoek om kanale vanaf die Okovangomoerasse te grawe om water na die Bamangwatoreservaat en sover as die Serowegebied te lei. Indien so 'n skema sou slaag, kan dit groot welvaart aan die bevolking bring. Dit sal dan moontlik wees om groot gebiede te besproei, aangesien die vloei van die Okovangorivier 20 persent groter is as dié van die Oranjerivier (Pretoria News, 14.2.1963).

Blanke boere, veral in die Ghanzidistrik, is belangrike suiwelprodusente, alhoewel die totale waarde van die produksie minder as R200,000 per jaar beloop. Die totale waarde van akkerbouproduksie (gewaardeer teen minder as R2,000,000 per jaar) word verkry van die Bantoe se tradisionele droëlandboerdery.

Die Bantoe het voor die koms van die Blanke reeds 'n groot verskeidenheid gewasse geproduseer. Kafferkoring (mabêlê) waaruit pap en bier gemaak word, is die belangrikste voedsel van die bevolking terwyl mielies (mmidi; mmôpô) en manna (lêbêlêbêle) op kleiner skaal verbou word. Die vernaamste ander voedsel is soetriet (nyôba mpse) en verskillende spesies grondboontjies (ditloo), boontjies (dinawa, dithodi) en kalbasse (marotse, maphutse, magapu, makatane). Tabak is vroeër op redelike groot skaal geproduseer maar aangesien dit vandag by die handelaar verkry kan word, het die produksie daarvan in onbruik geraak. As gevolg van die lae graanproduksie is die gebied genoodsaak om jaarliks vir eie gebruik in te voer. Alhoewel die gebrekkige reënval 'n baie belangrike oorsaak is van swak oeste, moet hierby nog gevoeg word: swak akkerboumetodes, magiese praktyk, beperkende regulasies, trekarbeid, onderhoudsproduksie, beperkings as gevolg van kommunale grondbesit en tradisionele grondgebruike ens. 
Die Tuliblok en in 'n mindere mate ook die Tatikonsessie bied geleenthede vir intensiewe akkerbou op vrugbare grond onder besproeiing. Die moontlikhede van die produksie van sekere produkte soos sitrus en die verhoging van die opbrengs van ander gewasse soos mielies, koring, grondboontjies, lusern en katoen is reeds gedemonstreer. Die vernaamste probleem wat gepaard gaan met ' $n$ toename in landbouproduksie is geleë in die vind van markte of om die produksie so elasties as moontlik te hou om in te pas by veranderde marktoestande.

Beesboerdery is die hoeksteen of liewers die fondament waarop hierdie Protektoraat se volkshuishouding rus. Die feit dat die uitvoer van beeste en veeteeltprodukte vir die omgewing van 70 persent van die totale uitvoerverdienste van die gebied verantwoordelik is, is ' $n$ aanwyser van die belangrikheid daarvan.

As gevolg van die droë klimaat word die grootste gedeelte van die landbouers by beesboerdery betrek. Die verspreiding van die beesbevolking is baie oneweredig. Die grootste persentasie van die beeste word in die oostelike Protektoraat aangetref, alhoewel klein konsentrasies in die Mana- en die Ghanzidistrikte en in die noordwestelike gedeelte van die Bamangwatoreservaat voorkom.

Volgens offisiële skatting was die veebevolking in 1958 soos volg: 1,315,000 beeste, 298,000 bokke, 91,000 skape, 26,000 donkies, 7,700 perde, 4,400 varke en 150,000 pluimvee.

In 'n gebied waar ongeveer 90 persent van die beesbevolking besit word deur die Bantoe, wie se lewensstandaard en onderwyspeil baie laag is, kan verwag word dat die organisasie van die binnelandse bemarking van beeste nie hoog ontwikkel is nie. Baie jare reeds ruil die Tswana, net soos die ander Bantoestamme in die Republiek, beeste vir voedsel, klere en ander kommoditeite of vir ander beeste. Onder die invloed van die Blanke het lewende hawe as ruilmiddel in belangrikheid toegeneem, en die verkoop aan handelaars teen kontant is by meeste van hulle vandag 'n belangrike bron van 
kontantinkomste. Sedert die opening van die abattoir te Lobatsi (in 1954) het die bemarking van beeste 'n aanmerklike verandering ondergaan. Hierdie abattoir is toegerus met moderne masjinerie en is in staat om tot 300 beeste per dag te slag. Sedert die ontstaan van die abattoir bemark die Bantoe steeds meer regstreeks by die abattoir instede van gebruik te maak van die dienste van die handelaar.

b) Ander primêre, sekondêre en huisbedrywe

(i) Mynbou

Die gestadige vraag na en die stabiele pryse van die meeste metale en sekondêre minerale sowel as die belangrikheid van voldoende toekomstige bronne is aanleidende oorsake van geologiese opnames in elke gebied. Betsjoeanaland, omring deur baie belangrike mineraalproduserende lande, hou groot moontlikhede in van bedekte mineraalneerslae van ekonomiese waarde.

Ten spyte van die inherente struikelblok van 'n sandbedekte oppervlak en die watertekort in baie dele van die land, is 'n groot verskeidenheid mineraalneerslae reeds ontdek. Goud word sedert 1866 in die Tatidistrik op klein skaal ontgin, terwyl die enigste ander gebied met gunstige aanduidings die Kwebeheuwels in die geweste van die Ngamimeer is, waar klein neerslae reeds gevind is.

Die afgelope 25 jaar reeds is die aanwesigheid van krisolietasbes op verskillende plekke, byvoorbeeld in die Tatigebied en Serowe bekend, maar die vernaamste neerslag is by Mosheneng, ongeveer 40 myl wes van Lobatsi in die Ngwaketsereservaat. Hierdie myn word sedert 1951 ontgin deur 'n Suid-Afrikaanse maatskappy, wat R200,000 daarin belê het. Daar is aanduidings dat die erts van ' $n$ besonder hoë gehalte is.

Onlangse geologiese opnames dui verder op die moontlikheid van 'n uitbreiding van die Waterbergsteenkoolneerslae tot binne die Kgatlareservaat en verder noordwaarts tot in die omgewing van Palapye in die Ngwatoreservaat. Hier het boorgate die bestaan van on- 
geveer 100,000,000 ton mediumgraadse steenkool ontbloot. Afgesien hiervan is neerslae fluoriet, hidromuskoviet, ystererts en koper (in die Ngwatoreservaat) ontdek. ' $n$ Neerslag van hoëgraad-bematiet is naby Mahalapye in dieselfde omgewing gevind, asook 'n neerslag van kianiet naby Francistown, waarvan die ontginning in 1957 gestaak is. By die Boesmankopermyn, 70 myl noordwes van Francistown, wat slegs 'n tydlank aan die begin van hierdie eeu ontgin is, is ' $n$ geologiese opname gemaak, wat aangetoon het dat daar genoegsame erts aanwesig is vir ontginning. Die meeste van hierdie mineraalverskynsels is nog maar in die opnamestadium. Dit is dus op hierdic stadium onmoontlik om hulle na waarde te skat.

Mineraaluitvoere gedurende 1959 was soos volg: goud R4,868, silwer R26, asbes R190,536 en mangaan R184,008. Dit toon 'n afname van $R 4,484$ in vergelyking met die vorige jaar, wat hoofsaaklik toegeskryf kan word aan 'n daling in die prys van asbes.

(ii) Sekondêre nywerhede

In Betsjoeanaland bestaan min noemenswaardige sekondêre nywerhede. Die enigste van belang is die Francistownse beenmeelfabriek (opgerig in 1953), die Tatiromery (opgerig in 1947) met sy aandeelhouers in die Republiek; die seepfabriek (opgerig in 1957) en abattoir (opgerig in 1954), albei in Lobatsi en verder die bounywerheid. Die totale uitvoer van botter, alles na SuidAfrika, lê in die omgewing van 300,000 lbs., terwyl ietwat meer as 1000 ton beenmeel jaarliks geproduseer word; in 1959 was die seepuitvoere 19,660 kaste, waarvan byna 9,000 na Suid-Afrika gegaan het. Van al die aktiwiteite onder hierdie hoof is dié van die abattoir ongetwyfeld die belangrikste.

As gevolg van die feit dat die tuisprodusent geen versekerde afsetgebied vir sy produkte gehad het nie en hy weens die periodieke uitbreek van bek- en klouseer dikwels gevoelige verliese ly, is pogings van owerheidsweë aangewend om 'n stabieler mark vir die vernaamste produk van die gebied te skep. Die gevolg was die daarstelling van die Lotbasi-abattoir deur die Koloniale Ont- 
wikkelingskorporasie, wat vandag beskou kan word as die slagaar van nywerheidsaktiwiteite in die gebied. Die uitvoerwaarde van beeskarkasse het van R236,942 in 1954 tot $\mathrm{R} 3,961,162$ in 1959 gestyg.

(iii) Huisbedrywe

In die tradisionele leefwyse van die Tswana het die huisbedrywe 'n belangrike rol gespeel. Die vernaamste bedrywe wat in 'n redelike mate vandag nog beoefen word, kan in die volgende klasse verdeel word, nl. vesel-, gras-, blaar- en rietwerk; been- en horingwerk; kralewerk; klei- en pottebakkery; houtwerk; leerwerk en diverse huisbedrywe. Hieruit blyk dus duidelik dat die nywerheidsprodukte van die Tswana dié is van 'n primitiewe selfgenoegsame gemeenskap.

\section{c) Trekarbeid}

Van die verskillende redes wat aangevoer word vir die bestaan van trekarbeid uit Betsjoeanaland, hoofsaaklik na die Republiek van Suid-Afrika, is die ekonomiese noodsaaklikheid daarvan verreweg die belangrikste. Loonarbeid in die Republiek vorm 'n onontbeerlike bron van inkomste vir die Protektoraat en dra onteenseglik by tot die algemene welvaart van die gebied. Dit beteken egter nie dat elke man as gevolg van ekonomiese redes uitgedryf word om te gaan werk nie. Afgesien van dié wat in die reservate werksaam is, is daar baie ander wat genoeg beeste besit om in hulle eie behoeftes te voorsien. Ander wat weer baie arm en behoeftig is, is blykbaar heeltemal tevrede om tuis te bly selfs al moet hulle die goedere wat deur die grootste meerderheid begeer word, ontbeer.

Die feit dat die Republiek vir die buitelandse Bantoes 'n besondere aantrekkingskrag besit, moet daaraan toe. geskrywe word dat Suid-Afrika die grootste ontwikkeling op die gebied van die mynwese en sekondêre nywerheid op die vasteland van Afrika belewe en daarom ook die grootste werkgeleenthede bied. Dit tesame met die loondifferensiaal vorm die grootste aantrekkingskrag. In die meeste gevalle word hier baie hoër lone as elders in Afrika betaal. 
Volgens die Bechuanaland Protectorate: Annual Re. port $(1959$; p. 10) word die totale manlike trekarbeid na die aangrensende gebiede op 21,598 gestel en op grond van inligting ingewin kan die syfer van 21,000 vir alle praktiese doeleindes as trekarbeid na Suid-Afrika beskou word, terwyl die balans na die Federasie en Suidwes. Afrika gaan. Gegewens verstrek deur die Kamer van Mynwese toon dat vandag ongeveer 12,000 Betsjoeanas in die goudmyne werksaam is, met 'n beraamde inkomste (kontant en in natura) van meer as R3 miljoen.

Die totale verdienste van alle trekarbeiders uit Bet. sjoeanaland na Suid-Afrika word op meer as R5 miljoen (kontant en in natura) beraam. Van hierdie verdienste word sowat R1,200,000 na Betsjoeanaland gestuur of ge. neem; hierdie bedrag word soos volg saamgestel: goedere R650,000 en kontant R550,000. Hieruit blyk dus duidelik dat die grootste gedeelte van die totale verdienste van trekarbeiders bestee word in die land waar hulle werksaam is. Die beraamde regstreekse finansiële voordele uit die trekarbeidstelsel wat aan die Protektoraat toeval, word op ongeveer R1,500,000 gestel. Dit sluit die goedere en kontant saamgeneem of gestuur sowel as die uitgawes ten behoewe van die aanwerwing van trekarbeiders binne die Protektoraat in.

Afgesien van die voorgenoemde voordele van trekarbeid, lê in die stelsel ook sekere sosiale euwels opgesluit wat nie oor die hoof gesien kan word nie. Die vernaamste daarvan is onder andere: permanente huisverlating, huweliksontrou, verswakking van die stamdissipline en die agteruitgang van die veeboerdery en landbou.

'n Algehele verbod op die huidige stelsel van trekarbeid sal hierdie probleme grootliks bekamp, maar dan moet voorsiening gemaak word vir loonarbeid binne die gebied om die lewenstandaard te handhaaf en uiteindelik te verhoog. Dit wil egter voorkom asof 'n verbod op trekarbeid groot finansiële opofferings vir heelwat Bantoes in die Protektoraat teweeg sal bring, aangesien die vooruitsigte van loonarbeid binne die gebied in die nabye toekoms uiters gering is. 


\section{d) Staatsfinansies}

In $1958 / 59$ was die totale inkomste $R 4,030,480$ terwyl die uitgawes $R 3,879,526$ beloop het met 'n gevolglike surplus van R150,954. Naas die hulpverlening (,grants in aid") deur die Verenigde Koninkryk ten bedrae van $\mathrm{R} 1,120,000$ en die Koloniale Ontwikkelings- en Welsynsfonds $(\mathrm{R} 659,896)$ is dit interessant om daarop te let dat doeane en aksyns van R520,856 soos oorbetaal deur die Republiek van Suid-Afrika een van die belangrikste bydraes aan die gebied uitmaak. Van die Protektoraat se totale uitgawes in 1958/59 is slegs $\mathrm{R} 1,729,728$ of ongeveer 20 persent deur eie inkomste gedek. Die openbare skuld op 31 Maart 1959 was R1,458,110.

\section{e) Die samestelling van die geografiese en netto}

volksinkomste

Die berekening van die netto volksinkome op sektorbasis is gemaak vir die jaar 1955. Hierdie berekenings word in tabel 1 aangetoon. Hieruit blyk dat (i) die geografiese en volksinkomste respektiewelik R19.6 mil. joen en R14.2 miljoen beloop; (ii) die landbousektor die belangrikste bydrae t.o.v. die volksinkomste lewer; (iii) die aandeel van die volksinkomste van die Bantoe en die Blankes, wat onderskeidelik 99 persent en 1 persent van die bevolking uitmaak, onderskeidelik 78 persent en 21 persent beloop; (iv) die blankes se inkomste hoofsaaklik uit die handel verdien word; en ( $v$ ) dat trekarbeid ' $n$ belangrike bydrae tot die volksinkomste van die gebied lewer.

'n Analise van die volksinkomste per capita op ras basis toon dat dié van die Bantoes en Blankes onderskeidelik R30 en R1128 was terwyl die volksinkomste per capita van die totale bevolking $\mathrm{R} 37.68$ beloop. Die jongste beskikbare volksinkomste per capita vir ander Afrikagebiede is soos volg:

$\begin{array}{lrlc}\text { Algerië } & \text { R146 } & \text { Kenia } & 56 \\ \text { Ethiopië + Eritrea } & 20 & \text { Malagasy Rep. } & 86 \\ \text { Fed. van Rhodesië } & & \text { Nigerië } & 50 \\ \quad \text { en Njassaland } & 94 & \text { Oeganda } & 40 \\ \text { Ghana } & 138 & \text { Tanganjika } & \text { R34 }\end{array}$




$\begin{array}{llcr}\text { Suid-Afrika: } & & \text { Bantoe } & 92 \\ \text { Blankes } & 820 & \text { Gemiddeld } & 276 \\ \text { Asiate } & 160 & \text { Verenigde Arabiese } & \\ \text { Kleurlinge } & 116 & \text { Republiek } & 78\end{array}$

f) Samestelling van die bruto kapitaalvorming

Binnelandse kapitaalvorming bestaan uit daardie deel van 'n land se produksie en invoer wat nie geduren de die rekenperiode verbruik of uitgevoer word nie, maar wat as toevoeging tot sy voorraad kapitaalgoedere dien. Kapitaalgoedere word ook gedefinieer as ,all goods pro duced for use in future productive processes - machinery, equipment, plants, buildings, other construction and works, and producer's stock of raw materials, semifinished goods" (United Nations, Concepts and definitions of Capital Formation, Julie 1953), d.w.s. goedere wat nie beskikbaar is om in die onmiddellike behoeftes van ver bruikers te voorsien nie, maar gebruik word in die produksie van ander goedere in die toekoms.

Die beraamde bruto kapitaalvorming - d.w.s. kapitaalvorming sonder inagneming van waardevermindering - word vir die vernaamste sektore in tabel 2 saamgevat.

Tabel 2. Beraamde Bruto Kapitaalvorming, 1955

Pos R'000

R'000

Openbare sektor:

Administrasie

Bantoeowerhede

Landbou:

Bantoes $\quad 1,040$

Blankes $\quad 428$

1,468

Private boukonstruksie

Blankes*

Nywerhede, handel en bankwese

* Alle Bantochutte wat in 1958 gebou is, is as kapitaalvorming in die landbou in berekening gebring. 


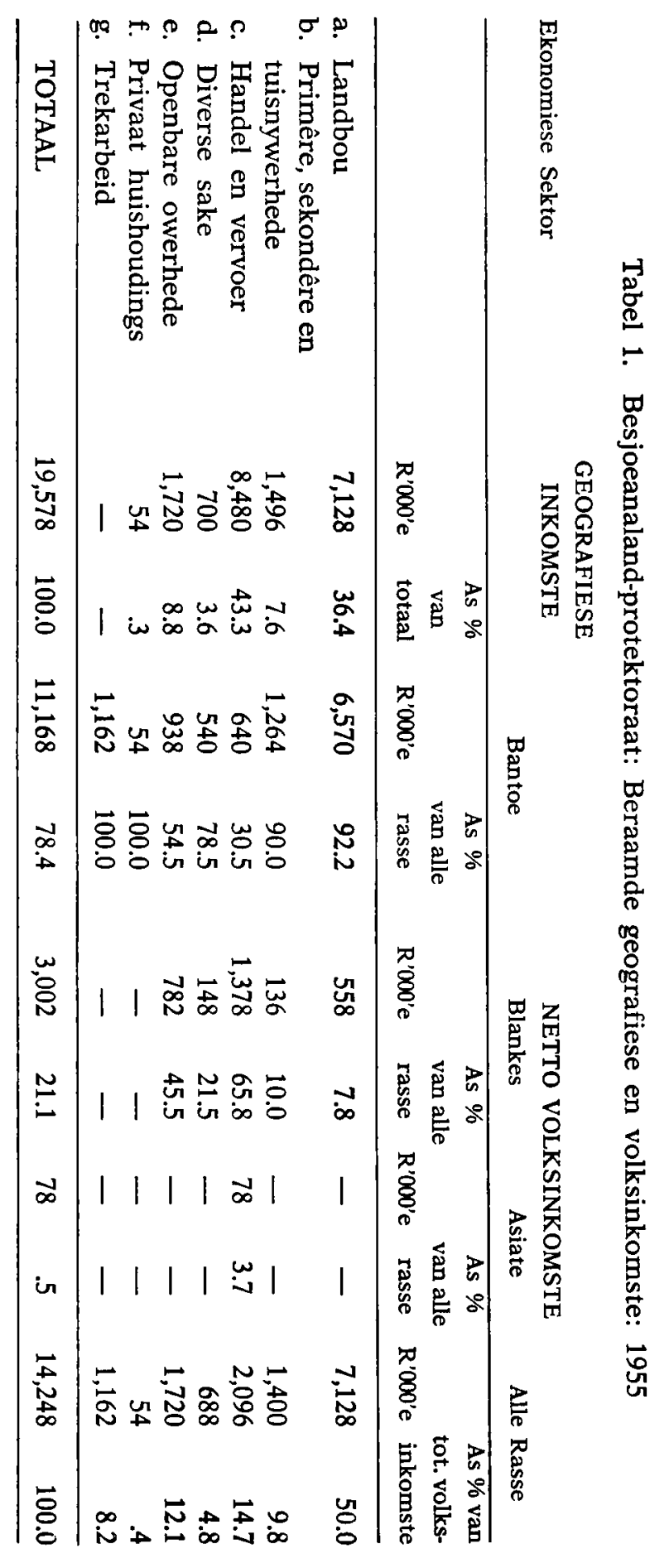


Hieruit blyk dat (i) kapitaalvorming in die landbouen openbare sektor die belangrikste was en (ii) dat die Bantoe vir ongeveer die helfte van die bruto kapitaalvorming in die gebied verantwoordelik was.

In die voorafgaande paragrawe is gelet op die kenmerkende eienskappe van die ekonomiese struktuur van die Betsjoeanalandse Protektoraat met besondere klem op die netto volksproduksie en die bruto kapitaalvorming wat 'n kwantitatiewe beeld gee van die ekonomiese bedrywighede van die gebied. Hierdie ontleding dien as basis van die voorwaardes vir die ontwikkeling van die gebied.

\section{Voorwaardes vir die ekonomiese ontwikkeling van die gebied}

In terme van die moderne samelewing met sy verdeling van arbeid, sy groot verskeidenheid van produksieen verbruiksgoedere, sy ekonomiese, finansiële en politieke instellings, sy wêreldwye mark, ens., kan Betsjoeanaland inderdaad as agterlik bestempel word. Een van die vernaamste oorsake van hierdie armoede moet toegeskryf word aan die feit dat ' $n$ relatiewe groot gedeelte van die hulpbronne van die gebied gekanaliseer word in die onderhoudsproduksie van die plaaslike gemeenskap, wat uiteraard weinig surplusse bo die primitiewe vereistes kan lewer. P. T. Bauer stel hierdie toestand soos volg: „Excessive and indiscriminate hospitality is a feature of subsistance economics where surpluses cannot be marketed and where it is therefore expected that these should be used for charity, and in particular for liberal entertainment of kinsmen, friends and visitors". (P. T. Bauer, West African Trade, Cambridge University Press, 1954, p. 8.).

Alhoewel die inkomste per capita in die gebied in vergelyking met Westerse standaarde laag is, kan die ekonomie nie sonder meer as stagnant beskou word nie, en moet daarop gelet word dat die onderhoudsekonomie geleidelik plek maak vir die geld- en markekonomie. Produksie van goedere vir die markekonomie word steeds 
deur 'n groter gedeelte van die bevolking beoefen. Die toestand het reeds ontwikkel waar geld geen onbekende ruilmiddel is nie en 'n belangrike faktor geword het binne die stamlewe.

Die belangrikste struikelblok van die gebied is die afwesigheid van enige noemenswaardige markte wat dit vir die landbouer uiteindelik die moeite werd maak om op gespesialiseerde grootskaalproduksie toe te spits. Dit is 'n gemeenplaas in literatuur oor die Ekonomie dat verdeling van arbeid bepaal word deur die omvang van die mark en dat enigiets wat die omvang van die mark vergroot ook die geleenthede vir meer gespesialiseerde produksie vergroot.

Die ekonomiese ontwikkeling van Betsjoeanaland, soos die van die meeste onderontwikkelde lande, hou 'n omvangryker en doeltreffender aanwending in van die beskikbare hulpbronne. Dit beteken onder andere 'n uitbouing van die plaaslike produksie, hoofsaaklik vir buitelandse markte, sowel as 'n algemene ekonomiese en sosiale reoriëntasie van sy inwoners.

\section{a) Buitelandse handel}

Tot dusver was die ontwikkeling van die gebied met sy beperkte binnelandse mark en relatief ongedifferensieerde volksproduksie in ' $n$ groot mate van die buitelandse handel afhanklik. Aangesien die buitelandse handel dus die mees strategiese groeipunt uitmaak, is dit van besondere belang om kortliks te let op die omvang van hierdie aktiwiteite en 'n moontlike uitbreiding daarvan.

Ten opsigte van die invoere word daarop gelet dat die waarde daarvan tussen 1927 en 1959 meer as vertienvoudig het (van $R 619,670$ in $1927 / 28$ tot $R 6,813,120$ in 1959. By gebrek aan geskikte prysindekse is dit nie moontlik om hierdie toename in terme van reële waardes uit te druk nie).

Die vernaamste invoere bestaan uit stapelvoedsel (kafferkoring, mielies en mieliemeel, koring en koringmeel), handels- en tekstielware met algemene handelsware as die belangrikste (ietwat minder as $\mathbf{5 0}$ persent van die totale invoere). 
Wanneer die herkoms van die invoere verder beskou word, is dit opmerklik dat Suid-Afrika nog al die jare die belangrikste leweransier was en dat die waarde van SuidAfrika-goedere van 1932 tot 1955 gewissel het tussen 56.2 en 79.7 persent van die totale invoere na die gebied; gedurende die afgelope dekade was die persentasie meer as 70 persent.

Die uitvoerhandel bestaan uitsluitlik uit die uitvoer van primêre kommoditeite soos beeste, huide, diereprodukte en minerale. Hierdie handel wat in $1927 / 28$ slegs R0.6 miljoen beloop het, het uitgebrei tot byna R7 miljoen in 1959 .

Alhoewel mineraaluitvoere nie groot in omvang is nie, beloop die uitvoer daarvan vir die afgelope aantal jare sowat 6 persent van die totale uitvoer terwyl (soos reeds opgemerk) veeteeltprodukte vir meer as 70 persent van die totale uitvoer verantwoordelik is.

Verder blyk dit dat Suid-Afrika en die Federasie van Rhodesië en Njassaland nog altyd die belangrikste afsetgebiede van die Protektoraat was. In 1955 het Suid-Afrika, die twee Rhodesiës en die res van die wêreld onderskeidelik 53.8, 33.6 en 12.6 persent van die totale uitvoere ontvang in teenstelling met $67,23.5$ en 9.5 persent vir die ooreenstemmende lande in 1959. Uit 'n ontleding van die uitvoerstatistiek blyk dit dat Suid-Afrika as afsetgebied vir die Protektoraat in belangrikheid toeneem. SuidAfrika is derhalwe nie alleen die grootste leweransier nie maar ook die grootste invoerder van Protektoraatprodukte. Die handelsbalans met Suid-Afrika toon 'n tekort van $\mathrm{R} 718,516$ in 1959.

Gebrek aan 'n groter verskeidenheid van uitvoerprodukte is een van die grootste leemtes in die volkshuishouding van die gebied - 'n groot afname in die uitvoerwaarde van beesvleis of beeste op die hoef sal verreweg die grootste gedeelte van die bevolking nadelig tref. ' $n$ Waardestyging sal weer die teenoorgestelde uitwerking hê. Daarom moet besondere aandag verleen word aan groter produkdifferensiasie.

Ten spyte van stremmende faktore soos (i) beperkte grootte van die mark, (ii) skaarste aan kapitaal en kre- 
dietinstellings (die Standard Bank van Suid-Afrika en Barclays Bank het elk takke op Francistown en Lobatsi, wat dan ook die enigste georganiseerde kredietinstellings in die gebied is) en (iii) gebrek aan geskoolde arbeid, bestaan daar op die oomblik tog moontlikhede vir die vestiging van sekere nywerhede wat nie alleen in die plaaslike behoeftes kan voorsien nie maar wat ook mettertyd kan uitvoer. Op grond van 'n ondersoek blyk dat benewens graanmeulens in die vernaamste graanproduserende distrikte, daar ook op Francistown, Mahalapye en Lobatsi onderskeidelik vestigingsmoontlikhede is vir 'n abattoir en 'n meubelfabriek, 'n stewel- en skoenfabriek, 'n looiery en vleisinmaakfabriek. Verder is die klere- en kombersbedryf ander moontlikhede wat ondersoek behoort te word. In verband met bedrywe wat op tuisnywerhede gebaseer is, kan oorweging geskenk word aan die uitbouing van veral vlegwerk en karosvervaardiging.

Die vernaamste bedryfsekonomiese kenmerke van hierdie nywerhede is dat dit in 'n groot mate gebruik kan maak van halfgeskoolde en selfs ongeskoolde arbeid. Met uitsondering van die abattoir en graanmeulens vereis hierdie nywerhede ook relatief min kapitaal.

Ten opsigte van toeristehandel kan opgemerk word dat afgesien van sy wilde diere, die gebied geen topografiese aantrekkingskrag vir ' $n$ toeris besit nie. 'n Aspek waaraan aandag verleen kan word, is die moontlikheid van die daarstelling van ' $n$ wildreservaat en 'n skema vir grootwildjag in die noordelike kroongrondgebied. Die opbrengs uit die jag kan vir die instandhouding en verbetering van die reservaat aangewend word.

b) Algemene ekonomiese en sosiale reoriëntasie van die bevolking

Benewens die rol van die buitelandse handel is daar 'n hele aantal ekonomiese en sosiale faktore wat die ontwikkeling van Betsjoeanaland bepaal. Menslike faktore is veral belangrik om die inskakeling van die nie-menslike hulpbronne soos die bodem, minerale ens. in die produksieproses moontlik te maak. Dit hang immers van die inisiatief en ywer van die inwoners self af om die traagheid of inersie te oorkom. 
Op grond van die lewenswyse van die grootste gedeelte van die bevolking kan beweer word dat die toekomstige ekonomiese ontwikkeling van die gebied nie alleen saamhang met die ontsluiting van sy natuurlike hulpbronne, die oordrag van kundigheid of ' $n$ verandering in die aanwending van produksiefaktore nie, maar ook met 'n proses van ekonomiese en sosiale reoriëntasie. Dit beteken dat die Bantoe nuwe houdinge, sienswyses, denkwyses, gewoontes, gebruike en vaardighede moet ontwikkel in die plek van sy kommunale sosiale lewe wat hy in sy stamverband het.

'n Ekonomiese en sosiale reoriëntasie impliseer onder andere: (i) 'n verandering in die stelsel van grondbesit; (ii) die prysgee van sy tradisionele verknogtheid aan vee; (iii) 'n verandering van dieet, kleredrag en behuising; (iv) die prysgee van die vryheid verbonde aan die landbou en die aanpassing by die dissipline wat deur die moderne ekonomiese lewe gestel word; en (v) die ontwikkeling van nuwe maatstawwe waaraan inspanning gemeet word - weereens 'n aanpassing by die eise van 'n geld- en winsvolkshuishouding.

Wanneer gelet word op die relatief stadige tempo waarteen sodanige verandering plaasgevind het in Westerse lande, wat reeds bekend is met ' $n$ geldhuishouding en reeds 'n relatiewe hoë peil van sosiale ontwikkeling bereik het, wil dit voorkom of sodanige aanpassing selfs stadiger sal plaasvind binne 'n gemeenskap soos dié van Betsjoeanaland, wat met geheel ander waardebegrippe as dié van die Weste bekend is.

Die "Organisation for European Economic Co-operation" merk in verband met ontwikkelingsaangeleenthede en sosiale strukture die volgende op: „While, however, the existing social structure undoubtedly limits the speed of development, it is at the same time the only solid foundation for the stability of the territories. Any measure, whatever might appear to be economic or technical justification, which so undermines this foundation as to deprive the people of their sense of direction, would delay genuine progress. The greatest care must, therefore, be exercised in this connection and no attempt must 
be made to force unduly the pace of development... The conditions of production are ... closely bound up with the structure of society, and if economic progress were to be pushed ahead too rapidly in the underdeveloped regions, serious problems might be created by the drastic changes in social structure that would be involved". (Investments in Overseas Territories in Africa, South of the Sahara, Parys, 1951, p. 23).

'n Volgende belangrike voorwaarde vir die ontwikkeling van die gebied is die samewerking van die betrokke gemeenskappe met die ontwikkelingsinstansies en 'n daadwerklike poging deur sy inwoners tot 'n verbetering van hulle lewenstandaard. Op ' $n$ vergadering van Unesco het John Abbink die saak soos volg gestel: „The single most important problem facing leaders in underdeveloped countries is that of convincing their people that economic progress comes from within; that it cannot be imposed from without or even greatly advanced unless there exists a widespread desire for national improvement so strong that the necessary temporary sacrifice will seem worthwhile to all who will be affected". (Special Problems in Industrialisation, Proceedings on the Unesco Conference on the Conservation and Utilization of Resources, Lake Success, N.Y., 1950, p. 232).

Tot dusver was die ervaring van landboubeamptes in die Protektoraat byvoorbeeld dat die nodige samewerking van die Bantoe meestal ontbreek en dat in sommige gevalle selfs 'n weerstand ondervind word. Die welslae wat in sommige reservate behaal is, gee egter rede tot 'n mate van optimisme vir die toekoms.

Benewens die voorafgaande is die finansiële faktore eweneens van groot belang by die ontwikkeling van ' $n$ land. In die ekonomiese literatuur is dit algemeen bekend dat die tempo van ontwikkeling onder andere 'n funksie is van die koers waarteen nuwe kapitaal gevorm word en waar die omvang van ontwikkeling weer onder andere ' $n$ funksie is van die bedrag van besparings of kapitaalfondse wat op 'n besondere tydstip beskikbaar is (H. J. J. Reynders, Nywerheidsontwikkeling in die Bantoegebiede van Suid-Afrika, D.Comm.-proefskrif, Universiteit 
van Pretoria, Mei 1955, p. 351. Kyk ook: United Nations: Measures for the Economic Development of Underdeveloped Countries, N.Y., 1951, p. 35).

'n Volledige opname van hierdie aspek bring aan die lig dat die binnelandse kapitaalbronne uiters beperk is en dat die ontwikkeling van die gebied in 'n groot mate saamhang met die beskikbaarstelling van buitelandse kapitaal. (Sien vir ontleding van hierdie aspek my proefskrif: Die probleem van Ekonomiese Ontwikkeling in Afrika met spesiale verwysing na Betsjoeanaland-protektoraat, Universiteit van Pretoria, Februarie 1959, pp. 231-245). Aangesien die private buitelandse belegger tot dusver weinig belang gestel het in beleggings in hierdie gebied, wil dit voorkom asof openbare buitelandse kapitaal in die vorm van Britse hulpverlening, net soos in die verlede, verreweg die belangrikste rol sal moet speel in die ontwikkeling van hierdie gebied.

Dit is seker gepas om af te sluit met enkele gedagtes oor die ekonomiese verhouding tussen die Republiek en Betsjocanaland.

\section{Slot}

Afgesien van dic feit dat Artikel 151 van die SuidAfrika Wet van 1909 voorsiening gemaak het vir die inlywing van die drie Protektorate, nl. Betsjoeanaland, Basoetoland en Swaziland by die destydse Unie van SuidAfrika, het dit verder nog 'n bylae bevat wat die grondslag van die administrasie van hierdie gebiede na oorname uiteensit. Omdat inlywing nie met Unifikasie geskied het nie, was dit nodig om 'n tussentydse reëling daar te stel vir die doeaneregte van daardie gebiede. Op 29 Junie 1910 is 'n ooreenkoms aangegaan waarvolgens ' $n$ deel van die doeane- en aksynsbelasting wat deur SuidAfrika ingevorder word, aan die Protektorate oorbetaal sal word. Die persentasie ingevorderde regte wat dientengevolge aan die gebiede oorbetaal moes word, is op 1.31097 persent vasgestel. Van hierdie bedrag sou Basoetoland .88575 persent, Betsjoeanaland .27622 persent en Swaziland .149 persent ontvang. Met uitsondering van 
die feit dat die gebiede sedert 1913 nie meer 'n aandeel kry in die aksynsregte wat in Suid-Afrika gehef word op bier en sterk drank nie, het hierdie persentasies onveranderd gebly. Uit inligting verstrek deur die Afdeling Doeane en Aksyns word opgemerk dat die totale doeane en aksyns wat aan die Protektorate oorbetaal is, gestyg het van $\mathrm{R} 80,716$ in $1910 / 11$ tot $\mathrm{R} 1,686,870$ in $1955 / 56$. 'n Toename dus van R1,606,154. Oor die periode 1952/53 tot 1958/59 het alleen Betsjoeanaland se aandeel van doeane en aksyns van R283,462 tot R520,856 toegeneem, d.w.s. ietwat minder as verdubbel.

Sonder om 'n volledige geskiedkundige relaas te gee oor die verloop van die Suid-Afrikaanse invoerregte, word waar slegs op gewys dat die verhouding van oorbetaling inderdaad bereken is op 'n tydstip toe al die partye nog maar hoofsaaklik agraries was. Sedert die Eerste Wêreldoorlog het die tempo van ontwikkeling binne Suid-Afrika versnel en is sy invoerbelasting hersien om binnelandse nywerhede te stimuleer en te beskerm. Namate die ontwikkeling voortgegaan het, het die belastingdruk meer oorgehel na goedere wat nie as noodsaaklik vir die lewensbestaan gegeld het nie. Luukse artikels het met die verhoging van die Republiek se lewenspeil dus al hoe meer bygedra tot die totaal van die invoer- en aksynsbelasting. Aangesien die ontwikkeling van die Republiek baie vinniger plaasgevind het as in die Protektorate, waar die Bantoes binne hulle stamverband min of meer dieselfde ontwikkelingspeil bly behou het, wil dit op die oog af voorkom asof hierdie gebiede tans 'n groter voordeel uit die oorbetalings geniet as waarop ingevolge die 1910 -ooreenkoms beplan is. 'n Grondige studie van hierdie aspek het 'n dringende noodsaaklikheid geword. ' $n$ Handhawing van die huidige koers van oorbetaling kan geregverdig word op ander as suiwer ekonomiese oorwegings.

Ten opsigte van die buitelandse handel is in vorige paragrawe reeds gewys op die feit dat Suid-Afrika as afsetgebied van die Protektoraat steeds meer in belangrikheid toeneem - uitvoere na Suid-Afrika het in 1959 sowat 67 persent van die Protektoraat se totale uitvoere 
beloop terwyl die gebied ook verreweg die meeste goedere uit die Republiek invoer: sowat 70 persent van die totale invoere. (Interessant is dit om daarop te let dat indien Brittanje sou toetree tot die Europese Gemeenskaplike Mark, die ses ledelande dit baie duidelik gestel het dat geen handelsverkeer tussen Suid-Afrika en Brittanje deur die Protektorate toegelaat sal word nie. Spesiale voorsiening sal gemaak word vir die handel tussen Brittanje en laasgenoemde gebiede.)

Verder lewer die Republiek 'n belangrike bydrae aan die gebied in die vorm van indiensneming van trekarbeiders, wat in groot getalle 'n heenkome hier kom soek.

Alles in aanmerking genome is dit baie duidelik dat Betsjoeanaland-protektoraat ekonomies besonder nou met die Republiek verbind is en selfs in 'n hoë mate daarvan afhanklik is.

P.U. vir C.H.O.

D. P. Erasmus.

1 Mei 1963. 